JURNAL PENJAMINAN MUTU

LEMBAGA PENJAMINAN MUTU

UNIVERSITAS HINDU NEGERI

I GUSTI BAGUS SUGRIWA DENPASAR

\title{
PENGEMBANGAN MODUL PEMBELAJARAN INTERAKTIF (MOBELIN) UNTUK MENINGKATKAN MUTU PEMBELAJARAN ALGORITMA DAN PEMROGRAMAN
}

\author{
Oleh \\ Andi Baso Kaswar', Nurjannah ${ }^{2}$ \\ ${ }^{1)}$ Universitas Negeri Makassar, ${ }^{2)}$ Institut Agama Islam Muhammadiyah Sinjai \\ a.baso.kaswar@unm.ac.id ${ }^{1}$, nurjannah310807@gmail.com ${ }^{2}$
}

diterima 20 April 2021, direvisi 06 Mei 2021, diterbitkan 31 Agustus 2021

\begin{abstract}
Abstrak
Penelitian ini bertujuan untuk mengembangkan modul pembelajaran interaktif untuk membantu mahasiswa Universitas Negeri Makassar dalam memahami materi algoritma dan pemrograman dasar khususnya pada situasi saat ini yang sedang dilanda pandemic covid-19 yang megharuskan pembelajaran dilakukan secara online. Penelitian ini dirancang dengan menggunakan model ADDIE (Analysis, Design, Development, Implementation, Evaluation). Untuk mendapatkan modul yang valid dan efektif, maka dilakukan pengujian validitas terhadap instrumen penelitian serta pengujian validitas terhadap modul yang dikembangkan. Modul yang telah dikembangkan kemudian dinilai oleh subjek penelitian untuk menentukan keefktifannya.

Berdasarkan hasil penelitian diperoleh bahwa MOBELIN dinyatakan memenuhi kevalidan dan keefektifan. Hasil ini diperoleh setelah dilakukan uji validitas oleh para ahli yang terdiri dari validasi instrumen pada keseluruhan aspek berada pada kategori valid yakni 3,32. Sementara itu, MOBELIN dikatakan efektif digunakan berdasarkan penilaian mahasiswa yang terdiri dari beberapa aspek yaitu pada aspek materi dengan skor 3,48 dengan kategori baik, aspek efektifitas dengan skor 3,41 pada kategori baik, aspek tampilan dengan skor 3,56 dengan kategori sangat baik, aspek kemudahan dalam mengakses dengan skor 3,60 dengan kategori sangat baik dan aspek keoptimalan dalam pembelajaran dengan skor 3,36 dengan kategori baik sehingga rata-rata skor secara keseluruhan adalah 3,45 dengan kategori baik. Sehingga,dapat disimpulkan bahwa MOBELIN dapat digunakan sebagai bahan ajar alternatif untuk meningkatkan mutu pembelajaran.
\end{abstract}

Kata Kunci : MOBELIN, Mutu, Algoritma \& Pemrograman 


\section{PENDAHULUAN}

Pada akhir tahun 2019 telah muncul virus mematikan baru yang dikenal dengan nama COVID-19. Virus ini kemudian menyebar ke seluruh dunia hanya dalam hitungan minggu, salah satunya adalah Indonesia. Penyebaran virus yang tidak mampu dihentikan dan semakin banyaknya orang yang terinfeksi virus mematikan ini mengakibatkan negaranegara di dunia mendeklarasikan penyebaran virus Covid-19 sebagai pandemic (Remuzzi \& Remuzzi, 2020; Tosepu et al., 2020). Tak terkecuali Indonesia, pada tahun 2020, kondisi pandemi ditetapkan oleh pemerintah Indonesia melalui kementerian kesehatan. Penetapan status pandemic mengakibatkan beberapa negara memberlakukan lockdown.

Penetapan status pandemi memberikan dampak yang luar biasa terhadap berbagai sendi kehidupan. Akibatnya cara hidup masyarakat seara global berubah secara drastis(Currie et al., 2020). Selain sektor ekonomi dan kehidupan social masyarakat, pendidikan adalah salah satu sektor yang juga terdampak luar biasa(Widayat, 2021). Penetapan status pandemi mengakibatkan Pemerintah melalui Kementerian Pendidikan dan Kebudayaan Republik Indonesia melarang dilaksanakannya proses belajar mengajar secara tatap muka di kelas (Kementerian Pendidikan dan Kebudayaan republik Indonesia, 2020). Pelarangan tersebut bertujuan agar dapat mencegah terjadinya penyebaran virus di lingkungan sekolah ataupun perguruan tinggi.

Kondisi tersebut di atas kemudian memaksa sekolah dan perguruan tinggi untuk secara tiba-tiba melakukan transformasi proses belajar mengajar (Iivari, Sharma, \& Ventä-Olkkonen, 2020). Solusi awal transformasi proses belajar mengajar yang diambil oleh institusi pendidikan untuk beradaptasi dengan kondisi pandemi yang berlangsung adalah dengan menggantikan proses belajar mengajar secara luring menjadi daring(Kholisho \& Marfuatun, 2020; Sulistyohati, 2020; Widayat, 2021; Patricia, 2020).

Dalam pembelajaran daring, selain motivasi dan sikap positif peserta didik, kunci keberhasilan proses belajar mengajar adalah kesiapan infrastruktur telekomunikasi baik itu perangkat computer, akses jaringan, dan paket data (Sulistyohati, 2020). Namun, perubahan proses belajar mengajar dari tatap muka di kelas menjadi daring dalam waktu yang sangat singkat memunculkan berbagai permasalahan baru, seperti kurang efektif dan efisiennya proses pembelajaran dan daya serap materi peserta didik sehingga menyebabkan mutu pembelajaran menurun. Hal tersebut disebabkan oleh berbagai faktor baik internal ataupun eksternal, diantaranya: ketidaksiapan infrastruktur lembaga pendidikan untuk melangsungkan pembelajaran daring; Infrastruktur telekomunikasi yang belum merata di seluruh daerah Indonesia; Kondisi ekonomi sebagian peserta didik yang tidak mendukung untuk membeli perangkat telekomunikasi dan paket data (Kholisho \& Marfuatun, 2020).

Jika ditinjau dari sudut pandang peserta didik, masalah yang dihadapi adalah sebagian peserta didik tidak memiliki perangkat yang mendukung dalam pelaksanaan proses belajar mengajar tatap muka secara daring. Kemudian kondisi jaringan internet yang tidak stabil mengakibatkan perlu usaha besar untuk mendapatkan sinyal internet seperti naik kegunung, pohon atau atap rumah. Namun setelah mendapatkan jaringan internet yang baik, mahasiswa kembali terkendala pada sumber listrik, serta paket data yang terbatas dan mahal. Hal-hal diatas akhirnya mengakibatkan peserta didik tidak dapat mengikuti pembelajaran secara daring dengan tepat waktu dan sepenuhnya.

Sedangkan pada sisi pendidik, disarankan untuk melaksanakan proses pembelajaran sesuai jadwal namun tidak semua mahasiswa dapat mengikuti kelas sesuai jadwal akibat permasalahan di atas. Pengajar juga bisa menyesuaikan kelas dengan beberapa peserta didik, namun tidak semua peserta didik bisa menyesuaikan dengan jadwal tersebut. Selain itu, pengajar juga tidak setiap saat dapat melayani peserta didik karena adanya kewajiban atau kelas lain yang harus dikerjakan. 
Pada Program Studi Teknik Komputer Universitas Negeri Makassar, pada awal masa pandemic Covid-19, salah satu media pembelajaran yang paling banyak digunakan dalam proses pembelajaran tatap muka secara daring adalah aplikasi Zoom dan Google Meet. Namun, dalam perjalanannya kendalakendala yang terjadi pada sisi pengajar dan peserta didik mengakibatkan proses belajar mengajar menjadi tidak efektif dan efisien sehingga capaian pembelajaran menjadi tidak bermutu.

Pada dasarnya baik itu sebelum dan selama berlangsungnya pandemi Covid-19, telah banyak upaya-upaya yang dilakukan dalam rangka meningkatkan efektifitas dan kualitas layanan proses belajar mengajar, baik itu secara online dan offline. Selain melakukan evaluasi terhadap proses belajar mengajar, upaya yang dilakukan dapat dilihat pada pengembangan metode pembelajaran yang diterapkan (Bibi, 2015; Udayana, Wirawan, \& Divayana, 2017), pengembangan media pembelajaran (Irawan \& Wirasasmita, 2019; Kurniawan, Suyatna, \& Suana, 2015; Nurbani, Koriaty, \& Puspitasari, 2019; Nurmayanti, Ferdiansyah, \& N, 2021; Saifuddin, Putro, \& Irianto, 2020; Syaharuddin \& Mandailina, 2017; Williyana, Kholisho, \& Fathoni, 2018; Wirasasmita \& Putra, 2018), dan pemanfaatan aplikasi pendukung proses belajar mengajar (Ariyan, Rokhmawati, \& Brata, 2020; Wulandari, 2021).

Dalam hal pembuatan media pembelajaran, terdapat beberapa bentuk inovasi yang dilakukan agar media pembelajaran yang dibuat dapat memberikan efektifitas tertinggi dalam proses belajar mengajar. Beberapa peneliti media pembelajaran mencoba mengembangkan media pembelajaran berbasis masalah (Nurmayanti et al., 2021), berbasis multimedia interaktif (Dharmayanti \& Oktarika, 2019; Siddik \& Kholisho, 2019), berbasis video turorial (Irawan \& Wirasasmita, 2019; Williyana et al., 2018; Wirasasmita \& Putra, 2018), berbasis augmented reality (Hakim, 2018), berbasis digital elektronik (Wirasasmita \& Uska,
2017), berbasis software pihak ketiga (Wulandari, 2021), dan juga dalam bentuk modul dan buku digital (Kholisho, 2017; Nurbani et al., 2019; Syaharuddin \& Mandailina, 2017).

Berdasarkan beberapa bentuk inovasi yang dilakukan tersebut, pengembangan media pembelajaran dalam bentuk modul pembelajaran adalah salah satu yang banyak dilakukan. Misalnya pengembangan media pembelajaran berbasis buku digital Elektronic Publication (epub) menggunakan software sigil untuk mata kuliah pemrograman dasar (Wirasasmita \& Uska, 2017). Buku digital yang dikembangakan disertai video dan gambar yang mempermudah pembacannya memahami teori berupa teks. Selanjutnya pengembangan modul pemrograman komputer berbasis Matlab (Syaharuddin \& Mandailina, 2017). Modul yang dikembangkan seperti modul pada umunya yang berisi teori mengenai pemrograman dasar berbasis Matlab. Bentuk inovasi lainnya adalah pengembangan modul pembelajaran interaktif pemrograman dasar bermuatan model pembelajaran problem based learning (Saifuddin et al., 2020). Modul yang dikembangkan berupa e-modul yang dimuat dalam bentuk aplikasi berbasis web dimana peserta didik dapat mempelajari modul secara mandiri dan mengerjakan soal Latihan secara langsung pada web tersebut. Terdapat pula pengembangan e-module pemrograman dasar berbasis masalah dalam menunjang pembelajaran di masa pandemi Covid-19 (Nurmayanti et al., 2021). Modul tersebut dikembangkan dengan menyisipkan metode pembelajaran berbasis masalah dalam konten materi yang disajikan. Modul tersebut juga dibuat dalam bentuk e-modul.

Secara umum, modul yang telah dikembangkan di atas melakukan pengembangan dalam hal konten, bentuk media (digital, online, dan konvensional), dan penerapan model pembelajaran pada konten modul. Modul digunakan pada kelas tatap muka ataupun kelas online melalui aplikasi seperti Zoom. Sehingga, agar dapat belajar dengan baik, mahasiswa sangat bergantung kepada kondisi jaringan internet dan sumber 
listrik. Namun, dalam kegiatan belajar dari rumah mahasiswa memiliki banyak kendala, diantaranya modul yang dikembangkan belum memperhatikan sudut pandang peserta didik yang membutuhkan penjelasan materi kapanpun dan dimanapun ia berada, utamanya pada saat diberlakukannya aturan belajar dari rumah pada masa pandemi Covid-19. Hal tersebut mengakibatkan peserta didik kesulitan mempelajari materi modul karena tidak dapat memperoleh penjelasan langsung dari pengajarnya.

Oleh karena itu, kami mengusulkan Pengembangan Modul Pembelajaran Interaktif (Mobelin) Dilengkapi QR-Code Video untuk Meningkatkan Mutu Pembelajaran Algoritma dan Pemrograman Dasar. Modul yang dikembangakan terdiri atas 12 BAB, 70 Gambar ilustrasi, dan 60 QR Code. QR Code yang ada pada modul akan mengarahkan peserta didik menuju Video penjelasan dosen jika discan menggunakan smartphone. QR code ini diletakkan pada setiap materi dan contoh program yang disajikan.

Kelebihan MOBELIN adalah dapat dicetak ataupun dibaca secara digital sehingga peserta didik dapat membacanya kapanpun dan dimanapun. Selain itu modul yang dilengkapi dengan gambar ilustrasi unik dan QR Code Video, mempermudah mahasiswa memahami dan mengakses video penjelasan materi terkait apabila ia kesulitan memahami teks pada modul. Dengan begitu peserta didik tidak hanya sekedar membaca modul secara mandiri namun juga seolah-olah dosennya berada di dekatnya menjelaskan materi terkait, kapanpun dan di manapun ia berada.

\section{METODE}

Penelitian ini adalah penelitian pengembangan atau lebih dikenal dengan Research and Development dengan menggunakan model ADDIE yang merupakan singkatan dari Analysis, Design, Development, Implementation dan Evaluation. Adapun subjek pada penelitian ini adalah 98 (Sembilan puluh delapan) mahasiswa Program Studi Teknik Komputer Universitas Negeri Makassar.

Rancangan alur penelitian berdasarkan model ADDIE adalah sebagai berikut (Sugiyono, 2016):

\section{Tahap Analysis}

Pada tahap ini, dilakukan analisis kebutuhan utuk mengidentifikasi masalah yang terjadi di lapangan (kebutuhan) dengan menggunakan metode wawancara, survey, observasi maupun angket.

\section{Tahap Design}

Pada tahap ini, peneliti membuat rancangan Modul Pembelajaran Interaktif (MOBELIN) berupa kerangka materi yang akan dibuat serta desain modul yang akan digunakan.

\section{Tahap Development}

Tahap pengembangan yang dilakukan berupa uji validitas yang dilakukan oleh tim pakar/validator dimana rancangan produk awal Modul Pembelajaran Interaktif (MOBELIN) yang telah didesain kemudian diajukan kepada validator untuk dilakukan penilaian atau validasi isi (validation content). Penilaian validator dilakukan untuk menguji validitas dari produk yang telah didesain sebelumnya. Validator melakukan penilaian dan memberikan saran/masukan untuk penyempurnaan produk. Rumus untuk mencari rata-rata hasil validasi adalah sebagai berikut (Syaharuddin \& Mandailina, 2017).

$$
\bar{X}=\frac{\sum_{i=1}^{n} \bar{V}_{l}}{n}
$$

Dimana $\bar{X}$ merupakan rata-rata total sedangkan $\bar{V}$ merupakan rata-rata masingmasing validator, dan $n$ adalah banyaknya validator. Adapun kategori yang digukan untuk menguji validasi adalah sebagai berikut. 
Tabel 1. Kriteria Uji Validasi

\begin{tabular}{|c|c|}
\hline Rata-rata & Kriteria \\
\hline $3,5 \leq \bar{X} \leq 4$ & Sangat Valid \\
\hline $2,5 \leq \bar{X}<3,5$ & Valid \\
\hline $1,5 \leq \bar{X}<2,5$ & Cukup Valid \\
\hline $\bar{X}<1,5$ & Tidak Valid \\
\hline
\end{tabular}

Setelah melakukan validasi, Langkah selanjutnya adalah melakukan revisi pada modul. Revisi ini dilakukan berdasarkan hasil penilaian serta saran yang diberikan oleh masing-masing validator. Setelah revisi selesai dilakukan, maka tahap selanjutnya adalah melakukan sosialisasi atau dengan kata lain mendemonstrasikan/mensimulasikan modul yang telah dibuat kepada objek penelitian.

\section{Tahap Implementation dan Evaluation}

Pada tahan implementation dan evaluation, peneliti melakukan uji coba penggunaan modul untuk memeriksa kepraktisan dan keefektifan modul pembelajaran interaktif (MOBELIN). Untuk lebih meyakinkan lagi, diberikan angket kepada subjek penelitian untuk mengetahui rata-rata hasil uji keefektifan modul.

\section{III.PEMBAHASAN}

Hasil analisis pada penelitian ini terbagi menjadi tiga bagian, yaitu analisis kebutuhan, pengembangan produk serta uji keefektifan produk (Saifudin \& Kuning, 2021). Adapun produk yang dikembangkan yaitu modul pembelajaran interaktif (MOBELIN). Pengembangan produk tersebut didasarkan pada kebutuhan institusi untuk meningkatkan mutu pada pembelajaran Algoritma dan pemrograman.

\section{Analisis Kebutuhan}

Pada tahap analysis, peneliti berupaya mendapatkan data mengenai gambaran tentang kebutuhan mahasiswa terhadap modul pembelajaran interaktif (MOBELIN). Analisis kebutuhan dilakukan dengan hasil angket kebutuhan dengan mahasiswa sebagai yang ditampilkan pada Tabel 2.

\section{Tabel 2. Hasil Analisis Kebutuhan}

\begin{tabular}{|l|c|c|}
\hline \multicolumn{1}{|c|}{ Aspek } & Setuju & $\begin{array}{c}\text { Tidak } \\
\text { Setuju }\end{array}$ \\
\hline $\begin{array}{l}\text { Kebutuhan akan modul yang membantu } \\
\text { dalam pemahaman konsep }\end{array}$ & $83 \%$ & $17 \%$ \\
\hline $\begin{array}{l}\text { Kebutuhan akan modul yang dilengkapi } \\
\text { dengan video }\end{array}$ & $92 \%$ & $8 \%$ \\
\hline Kebutuhan modul yang mudah diakses & $89 \%$ & $11 \%$ \\
\hline $\begin{array}{l}\text { Kebutuhan akan modul yang membantu } \\
\text { mahasiswa untuk belajar mandiri }\end{array}$ & $91 \%$ & $9 \%$ \\
\hline
\end{tabular}

Berdasarkan Tabel 2 hasil analisis kebutuhan tersebut terlihat bahwa mahasiswa membutuhkan modul pembelajaran yang interaktif dimana di dalam modul tersebut terdapat materi yang dapat membantu dalam memahami konsep, dilengkapi dengan video penjelasan, mudah diakses dan dapat

Pada tahap ini, dilakukan uji validitas untuk melakukan penilaian terhadap konten pada modul (validation content). Proses validasi ini dilakukan dengan memberikan membantu mahasiswa untuk belajar mandiri. Merujuk pada hasil tersebut, maka perlu dibuat Modul Pembelajaran Interaktif yang memudahkan mahasiswa untuk mempelajarinya secara mandiri (Handhika \& Kurniadi, 2016; Laili, 2019).

\section{Pengembangan Modul}

instrumen berisi indikator tentang modul pembelajaran yang dikembangkan.

Adapun aspek yang diuji validasi adalah aspek tampilan, materi memuat pemahaman 
konsep, efisiensi modul dan kesesuaian materi dengan video pembelajaran. Berdasarkan proses pengujian validitas oleh validator sebagaimana telah diuraikan pada tahap depelopment diperoleh hasil sebagai berikut.

Tabel 3. Hasil Validasi Ahli

\begin{tabular}{|l|c|c|}
\hline \multicolumn{1}{|c|}{ Aspek } & Rata-rata & Keterangan \\
\hline Tampilan modul menarik & 3,67 & Sangat Valid \\
\hline Materi memuat pemahaman konsep & 3,33 & Valid \\
\hline Efisiensi modul & 3,46 & Valid \\
\hline $\begin{array}{l}\text { Kesesuaian materi dengan video } \\
\text { pembelajaran }\end{array}$ & 3,72 & Sangat Valid \\
\hline \multicolumn{1}{|c|}{ Rata-rata } & $\mathbf{3 , 5 5}$ & Sangat Valid \\
\hline
\end{tabular}

Berdasarkan hasil validasi yang dilakukan oleh para ahli, diperoleh hasil bahwa pada aspek tampilan modul diperoleh rata-rata sebesar 3,67 dan berada pada kategori sangat valid. Sementara itu, untuk aspek materi diperoleh rata-rata sebesar 3,33 dan berada pada kategori valid. Untuk aspek efisiensi memeroleh rata-rata sebear 3,46 dan berada pada kategori valid. Sedangkan untuk aspek kesesuaian materi dengan video pembelajaran memperoleh rata-rata 3,72 dan berada pada kategori sangat valid. Sehingga, untuk ratarata keseluran aspek adalah 3,55 dengan kategori sangat valid.

Meskipun hasil validasi berada pada kategori sangat valid, akan tetapi penelitii masih menerima dan mempertimbangkan masukan dari para validator untuk dijadikan sebagai dasar dalam melakukan revisi modul pembelajaran.

\section{Uji Keefektifan}

Untuk menentukan bahwa modul pembelajaran interaktif ini efektif, maka persentase penilaian yang diberikan oleh mahasiswa harus melebihi angka 70\%. Hasil ini diperoleh setelah melakukan perhitugan rata-rata penilaian mahasiswa secara keseluruhan.

Angket keefektifan penggunaan modul pembelajaran interaktif (MOBELIN) terdiri dari lima aspek yaitu aspek materi, aspek efektifitas, aspek tampilan, aspek kemudahan dalam mengakses, serta aspek keoptimalan dalam pembelajaran.

Berdasarkan hasil angket keefektifan tersebut, terlihat bahwa mayoritas dari subjek penelitian memberikan respon yang positif. Selain itu, modul pembelajaran interaktif dikatakan efektif digunakan berdasarkan penilaian mahasiswa yang terdiri dari beberapa aspek yaitu pada aspek materi memperoleh rata-rata 3,48 yang termasuk pada kategori baik, aspek efektifitas dengan rata-rata 3,41 yang berada pada kategori baik, aspek tampilan dengan rata-rata 3,56 pada kategori sangat baik, aspek kemudahan dalam mengakses dengan rata-rata 3,60 pada kategori sangat baik dan aspek keoptimalan dalam pembelajaran dengan rata-rata 3,36 pada kategori baik sehingga rata-rata skor secara keseluruhan adalah 3,45 berada pada kategori baik.

Berdasarkan hasil tersebut dapat dismpulkan bahwa modul pembelajaran interaktif (MOBELIN) telah memenuhi kriteria uji keefektifan dengan kategori "baik". Kesimpulan tersebut sejalan dengan pendapat Prasetyo (Rahman et al., 2019) yang menyatakan bahwa uji keefektifan dapat digunakan untuk memberikan bukti bahwa model yang dikembangkan dapat mencapai tujuan yang telah ditetapkan.

Berikut ini adalah sampul modul pembelajaran interaktif (MOBELIN) yang dikembangan: 


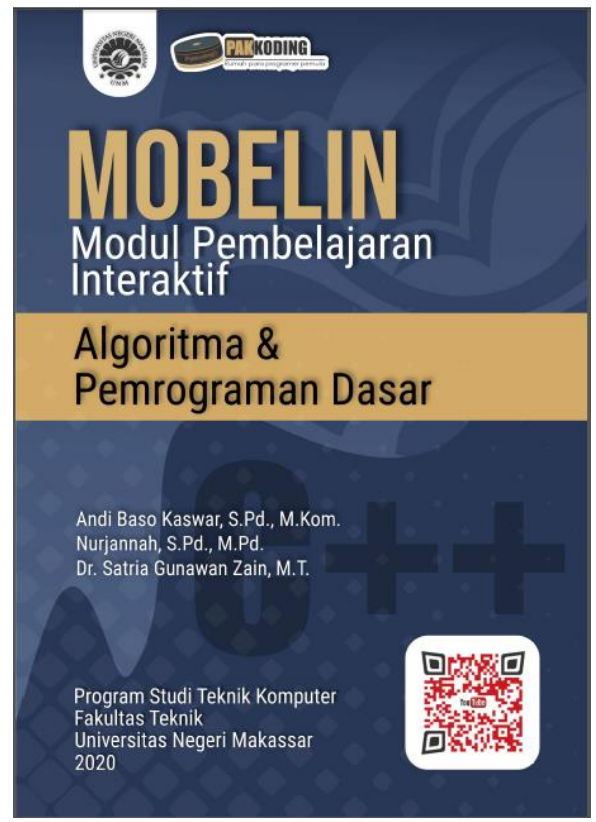

\section{Gambar 1. Tampilan Cover Modul Pembelajaran Interaktif (MOBELIN)}

Selain materi yang lengkap, modul pembelajaran interaktif (MOBELIN) juga memiliki barcode yang langsung menghubungkan ke video yang telah diupload ke Youtube. Video tersebut merupakan penjelasan dari materi yang ada di modul sehingga memudahkan mahasiswa untuk memahami materi yang ada. Berikut ini merupakan tampilan halaman yang dilengkapi dengan barcode.

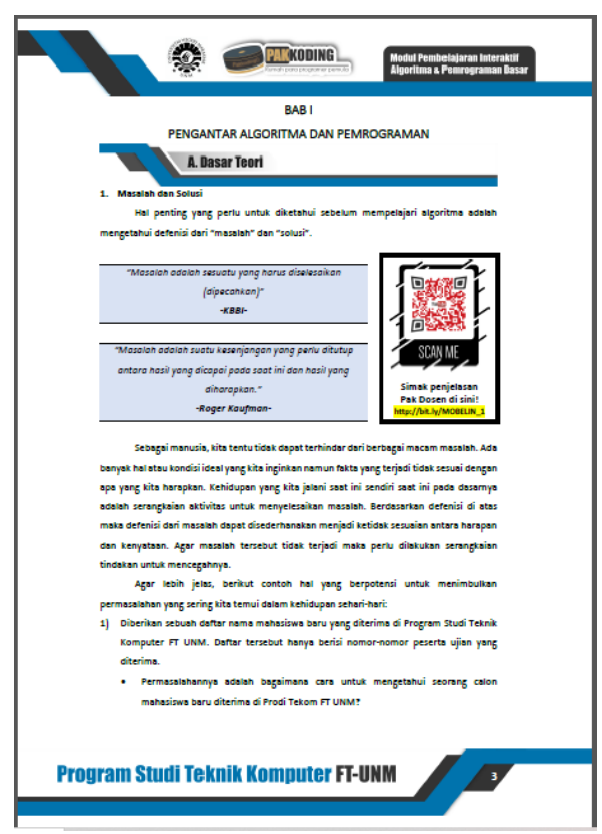

Gambar 2. Tampilan Halaman yang Memiliki Barcode 


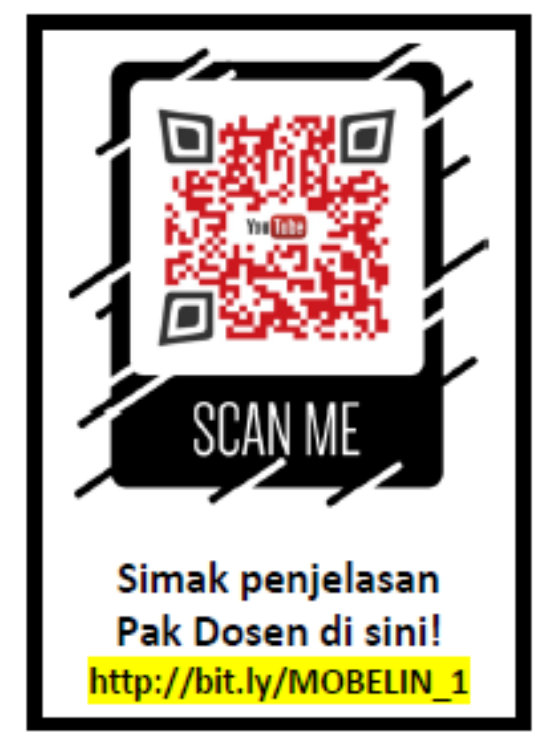

Gambar 3. Tampilan Barcode yang Langsung Terhubung ke Youtube

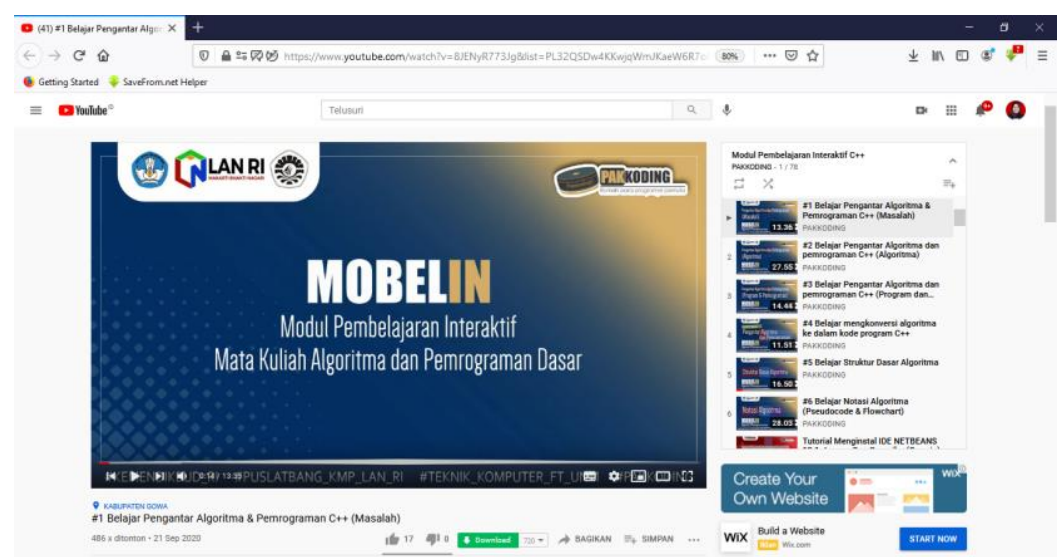

Gambar 4. Tampilan Video di Youtube Setelah Scan Barcode

\section{SIMPULAN}

Berdasarkan dari hasil studi pendahuluan yang dilakukan pada tahap analisis diperoleh bahwa modul pembelajaran interaktif (MOBELIN) sangat dibutuhkan oleh mahasiswa karena Sebagian besar dari mereka membutuhkan modul yang dapat diakses dengan mudah dan memiliki video pembelajaran untuk menjelaskan materi yang terdapat pada modul. Modul pembelajaran interaktif dikatakan sangat valid berdasarkan hasil validasi pada semua aspek dengan skor 3,55. Sementara itu, MOBELIN dikatakan efektif digunakan berdasarkan penilaian mahasiswa pada rata-rata keseluruhan aspek yaitu 3,45 berada pada kategori baik. Sehingga, dapat disimpulkan bahwa MOBELIN dapat digunakan sebagai bahan ajar alternatif untuk meningkatkan mutu pembelajaran.

\section{DAFTAR PUSTAKA}

Ariyan, F. R., Rokhmawati, R. I., \& Brata, K. C. (2020). Pengembangan Antarmuka Website E-Learning untuk Meningkatkan Minat Belajar Pemrograman Dasar Dalam Bahasa Pemrograman Java bagi Mahasiswa Fakultas Ilmu Komputer Universitas Brawijaya. Jurnal Pengembangan Teknologi Informasi Dan Ilmu Komputer E-ISSN, 2548(10), 964X.

Bibi, S. (2015). Efektivitas Penerapan Blended Learning Mata Kuliah Algoritma Dan Pemrograman. Jurnal Pendidikan Informatika Dan Sains, 4(2), 274-286. 
Currie, G., Hewis, J., Nelson, T., Chandler, A., Nabasenja, C., Spuur, K., ... Kilgour, A. (2020). COVID-19 impact on undergraduate teaching: Medical radiation science teaching team experience. Journal of Medical Imaging and Radiation Sciences, 1-10. https://doi.org/10.1016/j.jmir.2020.09.0 02

Dharmayanti, W., \& Oktarika, D. (2019). Pengembangan Media Pembelajaran Berbasis Multimedia Interaktif Untuk Guru Ipa Di Sekolah Menengah Pertama. Jurnal Pendidikan Informatika Dan Sains, $\quad 8(1), \quad 41$. https://doi.org/10.31571/saintek.v8i1.11 56

Hakim, L. (2018). Pengembangan Media Pembelajaran Pai Berbasis Augmented Reality. Lentera Pendidikan: Jurnal Ilmu Tarbiyah Dan Keguruan, 21(1), 59-72.

https://doi.org/10.24252/lp.2018v21n1i 6

Handhika, J., \& Kurniadi, E. (2016). Pengembangan Media Modul Berbasis Komputer Pada Matakuliah Fisika Modern. Jurnal Edukasi Matematika Dan Sains, 1(2), 1-8. https://doi.org/10.25273/jems.v1i2.115

Iivari, N., Sharma, S., \& Ventä-Olkkonen, L. (2020). Digital transformation of everyday life - How COVID-19 pandemic transformed the basic education of the young generation and why information management research should care? International Journal of Information Management, (June), 102183.

https://doi.org/10.1016/j.ijinfomgt.2020. 102183

Irawan, U., \& Wirasasmita, R. H. (2019). Media Pembelajaran Video Tutorial Interaktif Berbasis Adobe Flash Pada Mata Kuliah Pemrograman Dasar. EDUMATIC: Jurnal Pendidikan Informatika, 3(2), 84-90. https://doi.org/10.29408/edumatic.v3i2. 1654

Kementerian Pendidikan dan Kebudayaan republik Indonesia. (2020). Panduan Penyelenggaraan Pembelajaran pada Tahun Ajaran dan Tahun Akademik Baru di Masa Pandemi Covid-19: Satuan Pendidikan di Zona Kuning, Oranye dan Merah Dilarang Melakukan Pembelajaran Tatap Muka. In kemdikbud.go.id. Retrieved from https://www.kemdikbud.go.id/main/file s/download/d16ebb4e0e2245e

Kholisho, Y. N. (2017). Pengembangan Modul Pembelajaran Multimedia untuk Meningkatkan Minat dan Pemahaman Konsep Mahasiswa Prodi Pendidikan Informatika. EDUMATIC: Jurnal Pendidikan Informatika, 1(1), 17. https://doi.org/10.29408/edumatic.v1i1. 733

Kholisho, Y. N., \& Marfuatun, M. (2020). Daya Serap Pelaksanaan Mata Kuliah Kependidikan DiTengah Pandemi Covid-19. Edumatic : Jurnal Pendidikan Informatika, 4(1), 131-140. https://doi.org/10.29408/edumatic.v4i1. 2155

Kurniawan, D., Suyatna, A., \& Suana, W. (2015). Pengembangan Modul Interaktif Menggunakan Learning Content Development System Pada Materi Listrik Dinamis. Jurnal Pembelajaran Fisika, 3(6), 1-10.

Laili, I. (2019). Efektivitas Pengembangan EModul Project Based Learning Pada Mata Pelajaran Instalasi. Jurnal Imiah Pendidikan Dan Pembelajaran, 3, 306315.

https://ejournal.undiksha.ac.id/index.ph p/JIPP/article/download/21840/13513

Nurbani, N., Koriaty, S., \& Puspitasari, H. (2019). Pengembangan Modul Elektronik Mata Kuliah Sistem Digital Untuk Program Studi Pendidikan Tik. Jurnal Pendidikan Informatika Dan Sains, $\quad 8(1), \quad 52$. https://doi.org/10.31571/saintek.v8i1.10 07

Nurmayanti, N., Ferdiansyah, H., \& N, Z. (2021). Pengembangan E-Module Pemrograman Dasar Berbasis Masalah dalam Menunjang Pembelajaran di Masa 
Pandemi Covid-19. Edumaspul - Jurnal Pendidikan, 5(1), 22-30.

Patricia, A. (2020). College Students' Use and Acceptance of Emergency Online Learning Due to COVID-19. International Journal of Educational Research Open, 100011. https://doi.org/10.1016/j.ijedro.2020.10 0011

Rahman, H., Nurjannah, N., \& Syarifuddin, S. (2019). Aplikasi Expert System Berbasis Fuzzy logic untuk Mendiagnosa Gaya Belajar Dominan Mahasiswa Tadris Matematika IAIM Sinjai. JTAM | Jurnal Teori Dan Aplikasi Matematika, 3(2), 143.

https://doi.org/10.31764/jtam.v3i2.1044

Remuzzi, A., \& Remuzzi, G. (2020). COVID-

19 and Italy: what next? The Lancet, 395(10231), $1225-$

1228.https://doi.org/10.1016/S01406736(20)30627-9

Saifudin, M. F., \& Kuning, U. L. (2021). Pengembangan Instrumen Tracer Study Berbasis Cluster Sebagai Kontrol Mutu Lulusan. Jurnal Penjaminan Mutu 7(1), 1-9.

Saifuddin, F., Putro, S. C., \& Irianto, W. S. G. (2020). Pengembangan Modul Pembelajaran Interktif Pemrograman Dasar Bermuatan Model Pembelajaran Problem Based Learning untuk Memahamkan Konsep Pemrograman Siswa Kelas X Program Keahlian TKJ di SMK Cendika Bangsa Kepanjen.pdf. Jurnal Teknologi, Kejuruan, Dan Pengajarannya, 43(1), 51-61.

Siddik, B., \& Kholisho, Y. N. (2019). Pengembangan Modul Pembelajaran Perakitan Komputer Berbasis Multimedia Interaktif. EDUMATIC: Jurnal Pendidikan Informatika, 3(1), 13. https://doi.org/10.29408/edumatic.v3i1. 1389

Sugiyono. (2016). Metodologi Penelitian Kuantitatif, Kualitatif, dan $R \& D$. Alfabeta.

Sulistyohati, A. (2020). Pengukuran Elearning Readiness Pada Mahasiswa Sebagai Upaya Penerapan Pembelajaran
Jarak Jauh Masa Pandemi COVID-19. Edumatic: Jurnal Pendidikan Informatika, 4(2), 136-145. https://doi.org/10.29408/edumatic.v4i2. 2674

Syaharuddin, S., \& Mandailina, V. (2017). Pengembangan Modul Pemrograman Komputer Berbasis Matlab. JTAM | Jurnal Teori Dan Aplikasi Matematika, l(1), https://doi.org/10.31764/jtam.v1i1.1

Tosepu, R., Gunawan, J., Effendy, D. S., Ahmad, L. O. A. I., Lestari, H., Bahar, H., \& Asfian, P. (2020). Correlation between weather and Covid-19 pandemic in Jakarta, Indonesia. Science of the Total Environment, 725. https://doi.org/10.1016/j.scitotenv.2020. 138436

Udayana, N. N. A., Wirawan, I. M. A., \& Divayana, D. G. H. (2017). Pemrograman Berorientasi Objek Dengan Model Pembelajaran Project Based Learning Kelas Xii Rekayasa Perangkat Lunak. Jurnal Nasional Pendidikan Teknik Informatika (JANAPATI), 6(2), 128-139.

Widayat, P. (2021). Kualitas Pembelajaran Mahasiswa Selama Kuliah Online. Jurnal Penjaminan Mutu, 7(1), 504-505.

Williyana, B. A. I., Kholisho, Y. N., \& Fathoni, A. (2018). Pengembangan Media Pembelajaran Berbasis Video Tutorial Interaktif Pada Mata Pelajaran Teknik Animasi 2 Dimensi. EDUMATIC: Jurnal Pendidikan Informatika, 2(2), 52. https://doi.org/10.29408/edumatic.v2i2. 869

Wirasasmita, R. H., \& Putra, Y. K. (2018). Pengembangan Media Pembelajaran Video Tutorial Interaktif menggunakan Aplikasi Camtasia Studio dan Macromedia Flash. EDUMATIC: Jurnal Pendidikan Informatika, 1(2), 35. https://doi.org/10.29408/edumatic.v1i2. 944

Wirasasmita, R. H., \& Uska, M. Z. (2017). Pengembangan Media Pembelajaran Berbasis Buku Digital Elektronic 
Publication (Epub) Menggunakan

Software Sigil Pada Mata Kuliah

Pemrograman Dasar. Edumatic : Jurnal

Pendidikan Informatika, 1(1), 11-16. https://doi.org/10.29408/edumatic.v1i1. 732

Wulandari, I. A. G. (2021). Pemanfaatan Media Google Classroom Dalam Meningkatkan Mutu Pembelajaran Pada Masa Pandemi Covid-19 Di Ihdn Denpasar. Jurnal Penjaminan Mutu, 7(4), 45-52. 